\title{
Major Moderators Influencing the Relationships of Service Quality, Customer Satisfaction and Customer Loyalty
}

\author{
Hyung Seok Lee ${ }^{1}$ \\ ${ }^{1}$ Faculty of Business Administration, Chungbuk National University, Cheongju Chungbuk, South Korea \\ Correspondence: Hyung Seok Lee, Faculty of Business Administration, Chungbuk National University, 53 \\ Naesudong-ro Heungdeok-gu, Cheongju Chungbuk 361-763, South Korea. Tel: 82-43-261-3743. E-mail: \\ hyunglee@cbnu.ac.kr
}

Received: December 28, 2012 Accepted: January 6, 2013 Online Published: January 28, 2013

doi:10.5539/ass.v9n2p1

URL: http://dx.doi.org/10.5539/ass.v9n2p1

\begin{abstract}
This study examines some major variables moderating the relationships of service quality, customer satisfaction, and customer loyalty in mobile phone services. The study employed statistical analyses, such as reliability analysis, factor analysis, and hierarchical regression analysis. The results of the study reveal that service quality and customer satisfaction positively affect customer loyalty. In addition, service quality positively influences customer satisfaction. Hence, customers with high perceived service quality and satisfaction also have strong loyalty. Furthermore, the study verifies the fact that moderating variables positively influence the relationships among the aforementioned factors. Among customers with a high level of perceived value, the effect of service quality on customer satisfaction increases. In addition, when customers' perception of reasonable price increases, the impact of service quality on customer satisfaction increases as well. Finally, the study shows that as perceived switching cost increases, the relationship between satisfaction and customer loyalty strengthens.
\end{abstract}

Keywords: service quality, perceived price, perceived value, perceived switching cost

\section{Introduction}

Today's world of intensive competition requires firms to maintain the capability of high-quality service as sustainable competitive priority. Higher quality service providers will satisfy customers, leading them to become loyal customers. In addition, customer satisfaction has become the center of service marketing and operations management because it is a general proposition to be a significant antecedent of customer retention and repeat sales by positive word-of-mouth (Ryu and Han, 2010; Lee, 2010a).

The Korean mobile phone service market in the country is one with the highest mobile phone subscription rates in the Asia-Pacific region (Lee, 2010b). However, as the market is already saturated, in order to open the way for improving firm profit, service providers need to implement marketing strategies by focusing on customer retention (Turel and Serenko, 2006). There are three providers of mobile phone services (SK Telecom, Olleh KT, LG U+), with $50.3 \%, 30.9 \%$ and $18.8 \%$ of market shares, respectively. According to the Korea Communications Commission, the number of mobile phone users in Korea reached 53.2 million, which is more than the number of the population in August 2012. Since January 2004, the implementation of number portability regulations has allowed customers to retain their phone number when they switch to another service provider (Lee, 2010b). Thus, the current market situation can be considered as being extremely competitive. The changes in Korea's competitive mobile phone service market demonstrate that customer retention has been advocated as an important and more reliable source of superior performance (Lee et al., 2001). To sustain loyal customers, service providers should initiate customer satisfaction programs, such as service recovery, complaint management, and service quality warranty.

Prior studies examining customer retention have focused on customer satisfaction and service quality. Thus, many researchers have paid close attention to the causal relationship of service quality, customer satisfaction, and behavioral intentions (Cronin, Brady, Brand, Hightower and Shemwell, 1997). However, as a good number of customers pay attention to the perceived value, price and switching cost as well as quality and satisfaction, customers do not tend to always buy the highest quality service (Lee, 2010b; Olshavsky, 1985).

This study examines that higher quality service as well as the understanding of customer loyalty play a very 
important role in the mobile phone service market. It also suggests that, as with prior research, the concept of perceived value, perceived price, and perceived switching cost should be applied to the mobile phone service market in order to gain a deeper understanding of customer satisfaction and customer loyalty. The specific objectives of the study are threefold: (1) to investigate the effects of service quality on customer satisfaction and customer loyalty; (2) to examine the relationship between customer satisfaction and loyalty; and (3) to explore the moderating roles of perceived price, perceived value, and perceived switching cost in the relationship among service quality, customer satisfaction, and customer loyalty.

\section{Theoretical Background and Hypothesis}

\subsection{Service Quality, Customer Satisfaction, and Customer Loyalty}

Many definitions have attempted to describe what constitutes service quality. Higher-quality service indicates that service quality can be defined only by customers and that it occurs when a service organization provides service that satisfies the customer's needs (Metters et al., 2003). Thus, simply speaking, service quality is defined as the satisfaction of customer expectations. However, service quality is a complex construct which has multi-dimensions or multi-facet characteristics. To verify the dimensions of service quality, a considerable number of researches have been reported during the last twenty five years (Lee, 2010a). Specifically, Grönroos's (1984) two-dimensional model can be described as follows: 1) technical quality is "what a customer receives," and 2) functional quality is "how a service is provided or delivered." On the other hand, Parasuraman et al. (1985) conducted researches in several industry sectors to develop and refine SERVQUAL, a multiple-item instrument to quantify customers' global assessment of a company's service quality. Their scale involved expectations-perceptions gap scores along five dimensions: reliability, responsiveness, assurance, empathy, and tangibles (Metters et al., 2003). Three years later, Parasuraman and his colleagues (1988) defined perceived service quality as "the consumer's judgment about the superiority or excellence of a product," and confirmed the five-dimension model. However, Cronin and Taylor (1992) and Teas (1993) argued that performance measures as perceived quality is superior to the "perceptions-minus-expectations" measures. Hence, many previous studies revealed that service quality can be described as a form of attitude that is related but not equivalent to satisfaction, which results from the comparison of expectations with performance (Parasuraman et al., 1988; Bolton and Drew, 1991; Cronin and Taylor, 1992; Lee, 2010a). In addition, other conceptual and empirical studies suggest that service quality is comprised of service product, service environment, and service delivery (Rust and Oliver, 1994) or interaction quality, physical environment quality, and outcome quality (Brady and Cronin, 2001; Lee, 2011).

Although prior studies have mentioned that there has been much debate as to whether service quality dimensions are antecedents of customer satisfaction (Cronin and Taylor, 1992; Parasuraman et al., 1994; Zeithaml et al., 1996), in a majority of researches, service quality has a significant effect on customer satisfaction (Cronin and Taylor, 1992; Taylor and Baker, 1994; Levesque and McDougall, 1996; Zeithaml et al., 1996; McDougall and Levesque, 2000). For example, Cronin and Taylor's (1992) SERVPERF model provides a theoretical basis for the causal relationship between service quality and customer satisfaction. Jamal and Naser (2002) also reported that the core and relational dimensions of quality in the banking service revealed to be positively related to customer satisfaction. In addition, mobile phone service researches showed that service quality positively and significantly influences customer satisfaction (Kim et al., 2004; Tung, 2004; Turel and Serenko, 2006; Kuo et al., 2009; Lee, 2010a). Thus, it is possible to posit service quality as an antecedent of customer satisfaction.

Many studies have found a direct positive link between service quality perceptions and customer behavioral intentions (Boulding et al., 1993; Zeithaml et al., 1996). Cronin et al. (2000) conducted an empirical research via a large-scale survey of six industries and reported the causal effect of service quality on behavioral intentions. Ranaweera and Neely (2003) showed that there is a strong association between service quality and customer loyalty; that is, the higher the perceptions of service quality, the greater the level of repurchase intentions. Thus, service quality is an important driver of customer retention. In addition to customer retention, service quality is regarded to be a critical factor in the financial outputs of service firms. Service quality attracts customers with unsatisfactory emotion toward their service firms (Venetis and Ghauri, 2000; Lee, 2010a). Bloemer, Ruyter, and Wetzels (1998) and Aydin and Özer (2005) insisted that service quality is one of the key drivers to increase the number of loyal customers. Kuo et al. (2009) also found that there is a strong linear association between service quality and customer loyalty. Most recent studies on the association between service quality and behavioral intentions demonstrate that the two constructs have a strong causal relationship (Levesque and McDougall, 1996; Zeithaml et al., 1996; Cronin et al., 1997; Cronin et al., 2000). Therefore, Hypotheses 1 and 2 are proposed as follows: 
H1: Service quality has a positive and significant influence on customer satisfaction.

H2: Service quality positively and significantly influences customer loyalty.

Many service literatures also have reported that early research efforts focused on preventing confusion between customer satisfaction and service quality by determining whether there is any distinction between the two (Bitner, 1990; Cronin and Taylor, 1992; Oliver, 1993). Customer satisfaction results from comparing and experiencing a service quality which is encountered with what was expected (Oliver, 1980). Churchill and Surprenant (1982) insisted that satisfaction can be viewed as an attitude, due to be assessed as the sum of satisfactions with various attributes of a product or a service. Yi (1990) also showed that satisfaction can be conceived as an attitude. In addition, Caruana et al. (2000) and LaTour and Peat (1979) suggested that satisfaction can be considered as a post-decision experience construct, whereas an attitude can be viewed as a pre-decision construct. Rust et al. (1994) reported that customer satisfaction and delight are both strongly influenced by customer expectations and that the term "expectations" as used by behavioral researchers, which is "what is likely to happen, on average." They found a bewildering array of "expectations" that reflected what might, could, will, should, or better not happen. When someone says that the "service exceeded my expectations," what they generally mean is that the service was better than they had predicted it would be.

Zeithaml and Bitner (2000) defined customer satisfaction as a consumer's fulfillment response. In this regards, satisfaction can be considered as a judgment that "a product or service feature, or product or service itself, provides a pleasurable level of consumption-related fulfillment." Customer satisfaction also can be explained as the degree of customer's positive feeling toward a service provider. Thus, it is very meaningful for service firms to grasp the degree of customer perception in their services. On the other hand, a high level of customer satisfaction may have a positive effect on customer loyalty (Deng et al., 2009). Favorable behavioral intentions influence the ability of service providers to retain its customers to stay loyal to them as well as to recommend the service to other customers (Cronin and Taylor, 1992; Zeithaml et al., 1996).

According to Turel and Serenko (2006) and Kuo et al. (2009), in the mobile phone service market, there is a positive relationship between customer satisfaction and purchase intention. Deng et al. (2009) also found that customer loyalty is not only the ultimate object for customer satisfaction measurement, but also a key determinant of a firm's long-term viability. Fornell (1992) mentioned that the higher the level of customer satisfaction, the greater the level of customer loyalty. Jones and Sasser (1995) and Mittal and Kamakura (2001) attempted to link customer satisfaction to customer retention and found a significant non-linear relationship between the two constructs. Thus, Hypothesis 3 is proposed as follows:

H3: Customer satisfaction has a positive and significant influence on customer loyalty.

\subsection{Three Major Moderators}

\subsubsection{Perceived Value}

Perceived value has been known as a difficult concept to define and measure (Holbrook, 1994; Woodruff, 1997; Zeithaml, 1988; Lee, 2010a). The majority of studies define perceived value as a trade-off between the benefits and sacrifices (Zeithaml, 1988). Lee (2010a), mentioning that perceived value can be considered as the outcomes or the benefits customers gain relative to the total costs customers pay. Holbrook (1999) emphasizes that consumer value is the transaction between customer and the product from which value results from. According to his research, consumer value consists of eight components; efficiency, excellence, play, aesthetics, politics, morality, self-esteem, and spirituality.

Zeithaml (1988) defined consumer's perception of value as the following four concepts. First, value is a low price; second, value is whatever I want in a product; third, value is the quality I get for the price I pay; and finally, value is what I get for what I give. Zeithaml also expressed the four definitions by combining them into an aggregate definition: "perceived value is the consumer's overall assessment of utility of product based on perceptions of what is received and what is given" (Tung, 2004). Bolton and Drew (1991) also derived the perceived service value from the perceived product value mentioned above.

Perceived value plays a moderating role in the relation of service quality and satisfaction. Several researchers agree to the combined effects of perceived value and quality on satisfaction (Caruana, Money, and Berthon, 2000; Ryu and Han, 2010). Caruana et al. (2000) examined that perceived value has a significant moderating effect on the relationship between service quality and customer satisfaction. That is, the interaction between service quality and perceived value explained more of the variance in satisfaction than the direct influence of either service quality or perceived value on customer satisfaction (Ryu and Han, 2010). Thus, Hypothesis 4 is proposed as follows: 
H4: Perceived value has a significant influence on the relationship between service quality and customer satisfaction.

\subsubsection{Perceived Price}

Price is distinguished between objective price (the actual price of a product) and perceived price (the price as encoded by the consumer) (Jacoby and Olson, 1977). This distinction indicates that the objective monetary price is frequently not the price encoded by the consumer. Zeithaml (1988) also delineated the components of price: objective price, perceived nonmonetary price, and sacrifice. Some studies reveal that consumers do not always remember the objective prices of products, but they do encode prices in ways that are meaningful to them (Zeithaml, 1982, 1983, 1988). Perceived price can be defined as "the customer's judgment about a service's average price in comparison to its competitors" (Chen et al., 1994). Perceived price focuses on customers' concerns as to whether they are being charged more than or about the same as charged by competitors. Zeithaml (1988) insisted that consumer perception of value is highly related to the perception of price, and that the measurement of perceived value includes price perception. The National Council of the Green Consumers Network (2012) in Korea reported that many mobile phone subscribers were dissatisfied with the level and types of service charges. Ryu and Han (2010) found that the perceived price has a significant effect on the relationship between quality and customer satisfaction in the quick-casual restaurant industry. That is, customers' perception of a reasonable price enhances the effect of service quality on customer satisfaction. Thus, Hypothesis 5 is proposed as follows:

H5: Perceived price has a significant effect on the relationship between service quality and customer satisfaction.

\subsubsection{Perceived Switching Cost}

Switching cost is defined as the cost of changing services in terms of time, monetary value, and psychological factor (Dick and Basu, 1994; Lai et al., 2011). Switching cost includes the search cost (the cost of time spent for searching information) and the transaction cost (the cost of time and effort) (Schlesinger and Schulenburg, 1991). In the case of mobile phone services, the intention of customers to churn reduces due to switching costs, such as time spent for searching information about subscript conditions and the effort needed for changing mobile phone service providers. Additionally, switching cost not only produces barriers to customer churn, but also weakens the effect of satisfaction on customer loyalty. Jones et al. (2000) suggest that when the perceived switching cost is lower, the unsatisfied customer is less willing to remain with the current provider than the satisfied customer; when the perceived switching cost is higher, the unsatisfied customer keeps his/her current provider. Their findings indicate that the effect of customer satisfaction on repurchase intention decreases under conditions in which there exists a high switching cost (Lai et al., 2011). Lee et al. (2001) also examine that the link between customer satisfaction and loyalty is weak when switching cost increases. Their results show that when customers perceive that they must spend a greater amount of time and effort to search for service providers with a higher level of customer satisfaction, they are more willing to keep their current service providers regardless of how high or low the satisfaction is. Thus, Hypothesis 6 is proposed as follows:

H6: Perceived switching cost has a significant effect on the relationship between customer satisfaction and customer loyalty.

\section{Empirical Analysis}

\subsection{Measures}

To confirm the content validity, the measures for all constructs were taken from the existing literatures. Service quality refers to the customer's overall perceived assessment of service performance (Cronin et al., 1997; McDougall and Levesque, 2000, Lee, 2010b). Three items were used to measure the overall service quality: "Overall service quality of this provider" was assessed by using a seven-point scale. The first item was anchored by "poor" and "excellent." The second item was anchored by "inferior" and "superior," and the third item by "low standards" and "high standards." These items measured the overall perceived quality of services based on a series of adjectives.

Customer satisfaction is a customer's positive feeling about a service provider and the overall evaluation of the consumption experience (Lai et al., 2009; Oliver, 1997; Stank, Goldsby and Vickery, 1999). Two items were used to measure customer satisfaction: "Overall, how satisfied are you with this provider," and "Overall, how satisfied are you with the services you receive from this provider." These items were adapted from Lai et al. (2009) and measured on a seven-point Likert scale ranging from "very dissatisfied" to "very satisfied."

Customer loyalty is related to a service provider's ability to maintain its customers' loyalty and persuade them to recommend its services to potential customers (Zeithaml et al., 1996). Two items were used to measure customer 
loyalty (Cronin et al., 1997; Brady and Robertson, 1999): “The probability that I would use this service provider again" and "The likelihood that I would recommend this provider's services to a friend." These items were measured on a seven-point Likert scale ranging from "very low" to "very high." All measures and scales used in the present study have been already proved in prior service literatures (Brady and Robertson, 1999; Cronin and Taylor, 1992; Jamal and Naser, 2002; Oliver, 1997; Yi, 1990; Zeithaml et al., 1996; Zeithaml and Bitner, 2000).

Perceived value is a tradeoff between what customers gain and what they sacrifice (Cronin et al., 1997; Zeithaml, 1988, Lee, 2010a). Perceived value was measured by a single item: "Overall, the value of this provider's services to me is high," and was assessed on a seven-point Likert scale ranging from "strongly disagree" to "strongly agree."

Perceived price is the customer's judgment about a service's average price in comparison to its competitors (Chen et al., 1994; Ryu and Han, 2010). Perceived price was measured by a single item: "Overall, the price that this provider charges me is reasonable," and was assessed on a seven-point Likert scale ranging from "strongly disagree" to "strongly agree."

Perceived switching cost is what customers give up in order to obtain service, including monetary costs, such as money, and non-monetary costs, such as opportunity costs, time, and efforts (Cronin et al., 1997; Kuo et al., 2009; Zeithaml, 1988). Perceived switching cost was measured by a single item (Lai et al., 2011; Lee et al., 2001): "Overall, the perceived difficulty to change competitor's service is high," and was assessed on a seven-point Likert scale ranging from "strongly disagree" to "strongly agree."

\subsection{Data Collection}

Respondents in the study included 283 respondents who responded to face to face questions asked by trained interviewers in October 2011. They were drawn from the present service subscribers residing in Seoul. A stratified sampling technique was used for collecting the survey data (Lee, 2010b). The response rate in the survey was about $99 \%$. As shown in Table 1 the respondents' characteristics appear to be representative of mobile phone users in Korea. This study employed a hierarchical regression analysis in order to test the hypothesized relationships and used the SPSS 12.0 software. A total of $51.9 \%$ of respondents was male. Regarding age, $26.9 \%$ were between the ages of 10 and $19,29.7 \%$ were between the ages of 20 and $29,24.0 \%$ were between the ages of 30 and $39,11.7 \%$ were between the ages of 40 and 49 , and $7.8 \%$ were 50 over. A total of $51 \%$ had an associate's or a bachelor's degree, while $45 \%$ had a high school degree. Almost $54 \%$ were SK Telecom subscribers.

Table 1. Demographics of respondents

\begin{tabular}{lll}
\hline Variable & Item & Frequency (\%) \\
\hline \multirow{2}{*}{ Gender } & Male & $147(51.9)$ \\
& Female & $136(48.1)$ \\
& Under 20 & $76(26.9)$ \\
Age & 20 to under 30 & $84(29.7)$ \\
& 30 to under 40 & $68(24.0)$ \\
& 40 to under 50 & $33(11.7)$ \\
Education level & Over 50 & $22(7.8)$ \\
& High school & $128(45.2)$ \\
Monthly income & Associate's or Bachelor's degree & $143(50.5)$ \\
& Master's degree or above & $12(4.3)$ \\
& Under 1.5 million won & $92(32.5)$ \\
Service provider & 1.5 to under 3.0 million won & $85(30.0)$ \\
& 3.0 to under 4.5 million won & $63(22.3)$ \\
& Over 4.5 million won & $43(15.2)$ \\
& SK Telecom & $152(53.7)$ \\
& Olleh KT & $88(31.1)$ \\
& LG U+ & $43(15.2)$ \\
\hline
\end{tabular}




\subsection{Assessment of Reliability and Validity}

To assess the reliability and validity of the measures of each construct, this study used the internal consistency and exploratory factor analysis. The results of reliability and validity are shown in Table 2 . The scales showed acceptable reliability as all alpha coefficients were greater than 0.7 (Nunnally, 1978). The exploratory factor analysis was conducted along with a principal axis factoring analysis with OBLIMIN oblique rotation for the measurement items designed to measure multidimensional constructs. The analysis produced a solution with three factors, which accounted for $79.25 \%$ of the total variance explained. The values are considered satisfactory in social sciences.

Table 2. Results of reliability and validity

\begin{tabular}{lllll}
\hline Construct & Item & Loading & Total variance explained (Cumulative \%) & Cronbach's $\alpha$ \\
\hline \multirow{4}{*}{ Service quality } & SQ1 & 0.85 & & \\
& SQ2 & 0.97 & 57.95 & 0.95 \\
& SQ3 & 0.94 & & 0.91 \\
Customer satisfaction & CS1 & 0.91 & 73.65 & \\
& CS2 & 0.89 & & 0.78 \\
Customer loyalty & CL1 & 0.79 & \multirow{2}{*}{79.25} &
\end{tabular}

As presented in Table 2, the loading values were higher than 0.70 , and the cumulative total variance explained values that were higher than 50\%, suggesting that the validity of the scale was satisfied (Hair et al., 1998). The results, therefore, confirmed that the instrument had satisfactory validity.

\subsection{Hypothesis Test}

The regression model was conducted in order to test the hypotheses. Many researchers agree that one of the clearest ways to test the moderating and mediated effects is to use a hierarchical regression analysis based on Baron and Kenny's (1986) methodology (Aiken and West, 1991). They show that a moderator effect can be represented as the product of an independent variable and a factor, which specifies a condition for its operation (Lee et al., 2001). If the interaction terms are significant, the moderator hypotheses are supported. Additionally, if all of hypotheses 1,2, and 3 are supported, customer satisfaction becomes the mediator in the relationship between service quality and customer loyalty.

Table 3. Results of a hierarchical regression analysis

\begin{tabular}{llllllll}
\hline \multirow{2}{*}{ Independent variable } & \multicolumn{2}{l}{ Customer satisfaction } & \multicolumn{5}{l}{ Customer loyalty } \\
& Model 1 & Model 2 & Model 3 & Model 4 & Model 5 & Model 6 & Model 7 \\
\hline SQ & $0.52^{* * *}$ & $0.39^{* * *}$ & $0.27^{* * *}$ & & & $0.53^{* * *}$ & $0.24^{* * *}$ \\
SQ x PV & & $0.03^{* *}$ & $0.02^{* *}$ & & & & \\
SQ x PP & & & $0.03^{* *}$ & & & & \\
CS & & & & $0.67^{* * *}$ & $0.58^{* * *}$ & & $0.55^{* * *}$ \\
CS x PS & & & & & $0.02^{* * *}$ & & \\
$\mathrm{R}^{2}$ & 0.25 & 0.26 & 0.28 & 0.38 & 0.39 & 0.22 & 0.41 \\
$\mathrm{~F}$ & $93.13^{* * *}$ & $50.08^{* * *}$ & $36.03^{* * *}$ & $171.08^{* * *}$ & $90.96^{* * *}$ & $78.69^{* * *}$ & $98.44^{* * *}$ \\
$\Delta \mathrm{R}^{2}$ & - & 0.01 & 0.02 & - & 0.01 & - & 0.19 \\
$\Delta \mathrm{F}$ & - & $5.54^{* *}$ & $6.09^{* *}$ & - & $7.12^{* * *}$ & - & $92.56^{* * *}$ \\
\hline
\end{tabular}

Note: $\mathrm{SQ}=$ Service quality, $\mathrm{PV}=$ Perceived value, $\mathrm{PP}=$ Perceived price, $\mathrm{PS}=$ Perceived switching cost, $\mathrm{CS}=$ Customer satisfaction

${ }^{* *} \mathrm{p}<0.05,{ }^{* * *} \mathrm{p}<0.01$

Table 3 presents the results regarding the moderating role of the perceived price, perceived value, and perceived switching cost, as well as the mediating role of customer satisfaction. In Model 1, the result indicates that service quality $(\beta=0.52, p<0.01)$ is a significant antecedent of customer satisfaction. Thus, H1 is supported. Mode 6 shows that service quality $(\beta=0.53, \mathrm{p}<0.01)$ also has a significant positive effect on customer loyalty. Therefore, 
$\mathrm{H} 2$ is supported. The result of Model 4 also supports $\mathrm{H} 3$. That is, customer satisfaction $(\beta=0.67, \mathrm{p}<0.01)$ significantly affects customer loyalty. As indicated in Model 7 , when customer satisfaction $(\beta=0.55, p<0.01)$ is entered into the model, the size of the direct impact of service quality $(\beta=0.24, p<0.01)$ on customer loyalty is reduced compared with the result of Model 6 . The results also demonstrate a significant increment in the $\mathrm{R}^{2}$ of the model $\left(\Delta \mathrm{R}^{2}=0.19, \mathrm{p}<0.01\right)$. Thus, there is a significant mediating role of customer satisfaction on the relationship between service quality and customer loyalty. Additionally, customer satisfaction partially mediates the impact of service quality on customer loyalty.

Models 2, 3, and 5 present the results of the moderating effects. Model 2 indicates that the interaction of service quality and perceived value significantly affects customer satisfaction $(\beta=0.03, \mathrm{p}<0.05)$. The interaction's positive sign indicates that as perceived value increases, the association between service quality and customer satisfaction strengthens. Hence, hypothesis 4 is supported. This interactive term makes a significant contribution in the $\mathrm{R}^{2}$ of the model $\left(\Delta \mathrm{R}^{2}=0.01, \mathrm{p}<0.05\right)$. Hypothesis 5 is also supported because the interaction of service quality and perceived price significantly influences customer satisfaction $(\beta=0.03, p<0.05)$. The interaction's positive sign indicates that as perceived price increases, the relationship between service quality and customer satisfaction strengthens. This interactive term makes a significant contribution in the $R^{2}$ of the model $\left(\Delta R^{2}=0.02\right.$, $\mathrm{p}<0.05$ ). Model 5 shows that the interaction of customer satisfaction and perceived switching cost significantly affects customer loyalty. Therefore, hypothesis 6 is supported. The interaction's positive sign indicates that as perceived switching cost increases, the association between customer satisfaction and customer loyalty strengthens. This interactive term makes a significant contribution in the $R^{2}$ of the model $\left(\Delta R^{2}=0.01, p<0.01\right)$.

\section{Conclusion and Implication}

Many service researchers have studied the importance of service quality and customer satisfaction and their impacts on customer retention as well as on the firm's profitability. However, the challenges of service firms are to find other critical factors that moderate the relationships among service quality, customer satisfaction, and customer loyalty. Previous studies have mentioned that the perceived value, perceived price, and perceived switching cost are considered as moderators which play an important role in the relationships between service quality, customer satisfaction, and customer loyalty.

This study investigated the factors influencing the customer loyalty of Korea's mobile phone subscribers. Specifically, the study focused on the factors moderating the relationships of service quality, customer satisfaction, and customer loyalty. The results of the hierarchical regression analysis indicated that service quality and customer satisfaction significantly affected customer loyalty. The results also revealed that service quality was the significant antecedent of customer satisfaction. Thus, the results suggest that customer loyalty may be most significantly influenced by high-quality services, and that service quality is still critical for retaining customers and maintaining competitiveness. That is, if customers perceive a high-quality mobile phone service, they may be more likely to stay with their existing service provider and recommend the provider to others as well as encourage customers to share their positive experiences with others.

In addition, when customer satisfaction was entered into the link between service quality and customer loyalty, there was a significant mediating role of customer satisfaction on the relationship between service quality and customer loyalty. As such, prior studies have showed the importance of customer satisfaction and its effect on customer loyalty (Woo and Fock, 1999; Lee, 2010a, 2010b). Thus, customer satisfaction was a key factor in the relationship between customers and service providers.

The results of the moderating effects demonstrated that the interaction of service quality and perceived value significantly affected customer satisfaction. The interaction's positive sign indicated that as perceived value increases, the association between service quality and customer satisfaction strengthens. The interaction of service quality and perceived price significantly influenced customer satisfaction. The interaction's positive sign indicated that as perceived price increases, the relationship between service quality and customer satisfaction strengthens. The interaction of customer satisfaction and perceived switching cost significantly affected customer loyalty. The interaction's positive sign indicated that as perceived switching cost increases, the association between customer satisfaction and customer loyalty strengthens.

These results have important implications for practitioners; they should determine the exact roles of the perceived value, perceived price, and perceived switching cost in their customers' satisfaction and loyalty. Specifically, if perceived switching cost plays a crucial role in the relationship between customer satisfaction and customer loyalty, marketing practitioners should incorporate the cost into their customer loyalty relations. They need to discard the view that improvements in customer retention can only be achieved through improved customer satisfaction. By considering the roles of perceived value and price in the relationship between service 
quality and customer satisfaction, marketing practitioners may be better able to improve customer satisfaction.

This study was limited by the fact that the respondents were residents of Seoul. Therefore, future research using nation-wide data is warranted to strengthen the findings of this study.

\section{References}

Aiken, L. S., \& West, S. G. (1991). Multiple regression: testing and interpreting interactions. London: Sage Publications.

Aydin, S., \& Özer, G. (2005). The analysis of antecedents of customer loyalty in the Turkish mobile telecommunication market. European Journal of Marketing, 39(7/8), 910-925. http://dx.doi.org/10.1108/03090560510601833

Baron, R. M., \& Kenny, D. A. (1986). The moderator-mediator variable distinction in social psychological research: conceptual, strategic, and statistical considerations. Journal of Personality and Social Psychology, 51(6), 1173-1182. http://dx.doi.org/10.1037/0022-3514.51.6.1173

Bitner, M. J. (1990). Evaluating service encounters: the effects of physical surroundings and employee responses. Journal of Marketing, 54(2), 69-82. http://dx.doi.org/10.2307/1251871

Bloemer, J., Ruyter, K., \& Wetzels, M. (1998). On the relationship between perceived service, service loyalty and switching costs. International Journal of Service Industry Management, 9(5), 436-453. http://dx.doi.org/10.1108/09564239810238848

Bolton, R. N., \& Drew, J. H. (1991). A multistage model of customers' assessments of service quality and value. Journal of Consumer Research, 17(March), 375-384. http://dx.doi.org/10.1086/208564

Boulding, W., Kalra, A., Staelin, R., \& Zeithaml, V. (1993). A dynamic process model of service quality. Journal of Marketing Research, 30(February), 7-27. http://dx.doi.org/10.2307/3172510

Brady, M. K., \& Cronin, J. J., Jr. (2001). Some new thoughts on conceptualizing perceived service quality and value. Journal of Consumer Research, 17(4), 375-384.

Brady, M. K., \& Robertson, C. J. (1999). An exploratory study of service value in the USA and Ecuador. International Journal of Service Industry Management, 10(5), 469-486. http://dx.doi.org/10.1108/09564239910289003

Caruana, A., Money, A. H., \& Berthon, P. R. (2000). Service quality and satisfaction: the moderating role of value. European Journal of Marketing, 34(11), 1338-1352. http://dx.doi.org/10.1108/03090560010764432

Chen, L. J., Gupta, A., \& Rom, W. (1994). A study of price and quality in service operations. International Journal of Service Industry Management, 5(2), 23-34. http://dx.doi.org/10.1108/09564239410057663

Churchill, G. A. Jr., \& Surprenant, C. (1982). An investigation into the determinants of customer satisfaction. Journal of Marketing Research, 19(November), 491-504. http://dx.doi.org/10.2307/3151722

Cronin, J. J., \& Taylor, S. A. (1992). Measuring service quality: a re-examination and extension. Journal of Marketing, 56(July), 55-68. http://dx.doi.org/10.2307/1252296

Cronin, J. J., Brady, M. K., \& Hult, G. T. M. (2000). Assessing the effects of quality, value, and customer satisfaction on consumer behavioral intentions in service environment. Journal of Retailing, 76(2), 193-218. http://dx.doi.org/10.1016/S0022-4359(00)00028-2

Cronin, J. J., Brady, M. K., Brand, R. R., Hightower, R., \& Shemwell, D. J. (1997). A cross-sectional test of the effect and conceptualization of service value. Journal of Services Marketing, 11(6), 375-391. http://dx.doi.org/10.1108/08876049710187482

Deng, Z., Lu, Y., Wei, K. K., \& Zhang, J. (2009). Understanding customer satisfaction and loyalty: an empirical study of mobile instant messages in China. International Journal of Information Management, article in press.

Dick, A., \& Basu, K. (1994). Customer loyalty: toward an integrated conceptual framework. Journal of Academy of Marketing Science, 22, 99-113. http://dx.doi.org/10.1177/0092070394222001

Fornell, C. (1992). A national customer satisfaction barometer: The Swedish experience. Journal of Marketing, 56(1), 6-12. http://dx.doi.org/10.2307/1252129

Grönroos, C. (1984). A service quality model and its market implications. European Journal of Marketing, 18(4), 


\section{6-44. http://dx.doi.org/10.1108/EUM0000000004784}

Hair, J. F., Anderson, R. E, Tatham, R. L., \& Black, W. C. (1998). Multivariate data analysis. Englewood Cliffs, $\mathrm{NJ}$ :Prentice-Hall.

Holbrook, M. B. (1994). The nature of customer value: an anthology of services in the consumption experience. In R. T. Rust, \& R. L. Oliver (Eds.), Service quality: new directions in theory and practice (pp. 21-71). Sage Publications, Thousand Oaks, CA. http://dx.doi.org/10.4135/9781452229102.n2

Holbrook, M. B. (1996). Special session summary customer value C A framework for analysis and research. In K. P. Corfman, \& J. G. Jr. Lynch (Eds.), Advances in Consumer Research, 23 (pp. 138-142). Association for Consumer Research.

Jacoby, J., \& Olson, J. C. (1977). Customer response to price: an attitudinal, information processing perspective. In Y. Wind, \& P. Greenberg (Eds.), Moving Ahead with Attitude Research (pp. 73-86). Chicago: American Marketing Association.

Jamal, A., \& Naser, K. (2002). Customer satisfaction and retail banking: an assessment of some of the key antecedents of customer satisfaction in retail banking. International Journal of Banking Marketing, 20(4), 146-160. http://dx.doi.org/10.1108/02652320210432936

Jamal, A., \& Naser, K. (2002). Customer satisfaction and retail banking: an assessment of some of the key antecedents of customer satisfaction in retail banking. International Journal of Bank Marketing, 20(4), 146-160. http://dx.doi.org/10.1108/02652320210432936

Jones, M. A., Mothersbaugh, D. L., \& Beatty, S. E. (2000). Switching barriers and repurchase intention in service. Journal of Retailing, 76(2), 259-274. http://dx.doi.org/10.1016/S0022-4359(00)00024-5

Jones, T. O., \& Sasser, W. E. (1995, November-December). Why satisfied customers defect. Harvard Business Review, 88-99.

Kim, M., Park, M., \& Jeong, D. (2004). The effects of customer satisfaction and switching barrier on customer loyalty in Korean mobile telecommunication services. Telecommunications Policy, 28, 145-159. http://dx.doi.org/10.1016/j.telpol.2003.12.003

Kuo, Y., Wu, C., \& Deng, W. (2009). The relationships among service quality, perceived value, customer satisfaction, and post-purchase intention in mobile value-added services. Computers in Human Behavior, 25, 887-896. http://dx.doi.org/10.1016/j.chb.2009.03.003

Lai, F., Griffin, M., \& Babin, B. J. (2009). How quality, value, image, and satisfaction create loyalty at a Chinese telecom. Journal of Business Research, 62, 980-986.

Lai, L., Liu, C., \& Lin, J. (2011). The moderating effects of switching costs and inertia on the customer satisfaction-retention link: auto liability insurance service in Taiwan. Insurance Markets and Companies: Analyses and Actuarial Computations, 2(1), 69-78. http://dx.doi.org/10.1016/j.jbusres.2008.10.015

LaTour, S. A., \& Peat, N. C. (1979). Conceptual and methodological issues in satisfaction research. In W. L. Wilkie (Ed.), Advances in Consumer Research, 6. Association for Consumer Research, Ann Arbor, MI.

Lee, H. S. (2010a). Effects of perceived value and service quality on customer satisfaction in the mobile phone service market. INFORMATION: An International Interdisciplinary Journal, 13(4), 1207-1218.

Lee, H. S. (2010b). Factors influencing customer loyalty of mobile phone service: empirical evidence from Koreans. Journal of Internet Banking and Commerce, 15(2), 1-14.

Lee, H. S. (2011). Measuring the quality of fast-food service in Korea. INFORMATION: An International Interdisciplinary Journal, 14(1), 115-126.

Lee, J., Lee, J., \& Feick, L. (2001). The impact of switching costs on the customer satisfaction-loyalty link: mobile phone service in France. Journal of Services Marketing, 15(1), 35-48. http://dx.doi.org/10.1108/08876040110381463

Levesque, T., \& McDougall, G. H. G. (1996). Determinants of customer satisfaction in retail banking. International Journal of Bank Marketing, 14(7), 12-20. http://dx.doi.org/10.1108/02652329610151340

McDougall, G. H. G., \& Levesque, T. (2000). Customer satisfaction with services: putting perceived value into the equation. Journal of Services Marketing, 14(5), 393-410. http://dx.doi.org/10.1108/08876040010340937

Metters, R., King-Metters, K., \& Pullman, M. (2003). Successful Service Operations Management. Thomson South-Western. 
Mital, V., \& Kamakura, A. (2001). Satisfaction, repurchase intent, and repurchase behavior: investigating the moderating effect of customer characteristics. Journal of Marketing Research, 38(February), 131-142. http://dx.doi.org/10.1509/jmkr.38.1.131.18832

National Council of the Green Consumers Network Report. (2012). Retrieved from http://www.gcn.or.kr

Nunnally, J. C. (1978). Psychometric Theory. McGraw-Hill.

Oliver, R. L. (1980). A cognitive model of the antecedents and consequences of satisfaction decisions. Journal of Marketing Research, 17(November), 460-469. http://dx.doi.org/10.2307/3150499

Oliver, R. L. (1993). A conceptual model of service quality and service satisfaction: compatible goals, different concepts. In T. A. Swartz, D. E. Bowen, \& S. W. Brown (Eds.), Advances in Service Marketing and Management: Research and Practice (2nd ed.). JAI Press, Greenwich, CT, 65-85.

Oliver, R. L. (1997). Satisfaction: A Behavior Perspective on the Consumer. NY: McGraw-Hill.

Olshavsky, R. W. (1985). Perceived quality in consumer decision making: an integrated theoretical perspective. In J. Jacoby, \& J. Olson (Eds.), Perceived Quality. Lexington Books, Lexington, MA.

Parasuraman, A., Zeithaml, V. A., \& Berry, L. L. (1988). SERVQUAL: a multiple-item scale for measuring consumer perceptions of service quality. Journal of Retailing, 64(Spring), 2-40.

Parasuraman, A., Zeithaml, V. A., \& Berry, L. L. (1994). Reassessment of expectations as a comparison standard in measuring service quality: implications for further research. Journal of Marketing, 58(January), 111-124. http://dx.doi.org/10.2307/1252255

Ranaweera, C., \& Neely, A. (2003). Some moderating effects on the service quality-customer retention link. International Journal of Operations and Production Management, 23(2), 230-248. http://dx.doi.org/10.1108/01443570310458474

Reichheld, F. F. (1996). The Loyalty Effect: the Hidden Force behind Growth, Profits, and Lasting Value. Boston, MA: Harvard Business School Press.

Rust, R. T., \& Oliver, R. L. (1994). Service quality: insights and managerial implications from the frontier. In R. T. Rust, \& R. L. Oliver (Eds.), Service Quality: New Directions in Theory and Practice (pp. 1-19). Thousand Oaks, CA: Sage Publication. http://dx.doi.org/10.4135/9781452229102.n1

Rust, R., Zahorik, A., \& Keiningham, T. (1994). Return on Quality. Probus Publishing.

Ryu, K., \& Han, H. (2010). Influence of the quality of food, service, and physical environment on customer satisfaction and behavioral intention in quick-casual restaurants: moderating role of perceived price. Journal of Hospitality and Tourism Research, 34(3), 310-329. http://dx.doi.org/10.1177/1096348009350624

Schlesinger, H., \& Schulenburg, J. M. (1991). Search costs, switching costs and product heterogeneity in an insurance market. Journal of Risk and Insurance, 58(1), 109-119. http://dx.doi.org/10.2307/3520051

Stank, T. P., Goldsby, T. J., \& Vickery, S. K. (1999). Effect of service supplier performance on satisfaction and loyalty of store managers in the fast food industry. Journal of Operations Management, 17(4), 429-447. http://dx.doi.org/10.1016/S0272-6963(98)00052-7

Taylor, S. A., \& Baker, T. L. (1994). An assessment of the relationship between service quality and customer satisfaction in the formation of customers' purchase intentions. Journal of Marketing, 58(Summer), 163-178.

Teas, R. K. (1993). Expectations, performance evaluation, and consumer perceptions of quality. Journal of Marketing, 57(October), 18-34. http://dx.doi.org/10.2307/1252216

Tung, L. L. (2004). Service quality and perceived value's impact on satisfaction, intention and usage of short message service (SMS). Information Systems Frontiers, 6(4), 353-368. http://dx.doi.org/10.1023/B:ISFI.0000046377.32617.3d

Turel, O., \& Serenko, A. (2006). Satisfaction with mobile services in Canada: an empirical investigation. Telecommunications Policy, 30, 314-331. http://dx.doi.org/10.1016/j.telpol.2005.10.003

Venetis, K. A., \& Ghauri, P. N. (2002). The importance of service quality on customer retention: an empirical study of business service relationships. Proceedings of the Marketing in a Global Economy Conference, Buenos Aires, June 28-July 1, 215-224.

Woo, K., \& Fock, H. K. Y. (1999). Customer satisfaction in the Hong Kong mobile phone industry. The Service 
Industries Journal, 19(3), 162-174. http://dx.doi.org/10.1080/02642069900000035

Woodruff, R. B. (1997). Customer value: the next source for competitive advantage. Journal of the Academy of Marketing Science, 25(2), 139-153. http://dx.doi.org/10.1007/BF02894350

Yi, Y. (1990). A critical review of consumer satisfaction. In V. A. Zeithaml (Ed.), Review of Marketing (pp. 68-123). American Marketing Association, Chicago, IL.

Zeithaml, V. A. (1982). Consumer response to in-store price information environments. Journal of Consumer Research, 8(March), 357-369. http://dx.doi.org/10.1086/208876

Zeithaml, V. A. (1983). Conceptualizing and measuring consumer response to price. In R. P. Bagozzi, \& A. M. Tybout (Eds.), .Advances in Consumer Research (vol. 10, pp. 612-616). Ann Arbor, MI: Association for Consumer Research.

Zeithaml, V. A. (1988). Consumer perceptions of price, quality, and value: a means-end model and synthesis of evidence. Journal of Marketing, 52(July), 2-22. http://dx.doi.org/10.2307/1251446

Zeithaml, V. A., \& Bitner, M. J. (2000). Services Marketing: Integrating Customer Focus across the Firm (2nd ed.). Boston: McGraw-Hill.

Zeithaml, V. A., Berry, L. L., \& Parasuraman, A. (1996). The behavioral consequences of service quality. Journal of Marketing, 60(April), 31-46. http://dx.doi.org/10.2307/1251929 